\section{Canada's medical council wants larger role} Research Council of Canada. 1,500 people. The issue was debated by
Quebec. Next month, the Medical Research Council (MRC) of Canada is expected to endorse a long-term plan for a revolutionary change of role. From being a conservative, reactive fund-granting body little known outside biomedical research circles, it intends to become what its president, Henry Friesen, calls "the voice of Canadian medical and health-related research".

Beneath the lofty rhetoric, however, lies the down-to-earth question of whether the country can afford the council's new-found voice. And researchers worry that their funding will be squeezed unless the budget is increased.

The new direction would take the council far beyond the awarding of biomedical research project and research training funds after peer-review, its principal activity since its founding in 1969. It would make it the leading actor in all areas of health research, including epidemiological, disease prevention and environmental health studies as well as evaluation of treatment effectiveness. It would become, in effect, the Health

Its decision grew out of a complicated consultative process involving more than some 100 representatives of the health sciences, government and the private sector at a national conference on 12-13 May, following 16 workshops at universities across Canada.

The expansion, which would be expensive, comes at a time when the federal government is trying to pay off a national debt of Can $\$ 420,000$ million (US $\$ 300,000$ million). Brian Mulroney, the prime minister, has identified science and technology as one of the building blocks of Canada's competi- tiveness, but has found it difficult to show his support for science while keeping a tight rein on federal expenditures.

"The research component in our country makes us the finest country in the world", he told conference delegates. "I believe you and the institutes you represent, which look after our well-being, our health, our children and our scientific future, perform the most important work in Canada".

Unfortunately, Mulroney said, he inherited a situation upon becoming prime minister in which "we spend $\$ 43$ billion to service our debt on revenues of $\$ 28$ billion". The result, he said, is that "I don't have the resources to give you what you need".

Much was made at the conference of the fact that MRC and the other two research fund-granting councils have been promised an increase of 4 per cent a year for the next four years. What nobody mentioned was that the annual average inflation rate for the past year was 5.6 per cent.

Friesen thinks that, the gloomy financial picture notwithstanding, now is the time to enlarge MRC's scope because "health research must ultimately include the whole spectrum of health-related activities". Rigorous analysis of health care costs, he believes, could help to curb the steady growth of an annual bill, now $\$ 70,000$ million.

Friesen does not believe that the new plan will lead to a reduction in research funds for basic research, but rather the opposite. More partnerships and joint ventures with other government agencies, voluntary foundations and industry will lead to an increase in research funding sufficient to make the health industry a major contributor to the country's economy, he says.

David Spurgeon

\section{Congress slashes "silly titles"}

Washington. Defying scientific groups, who accused Congress of making a mockery of the peer review process, legislators last week voted to go ahead and seek the deletion of 32 projects with "silly titles" that had been merit reviewed and approved by the US National Science Foundation (NSF) and the National Institutes of Health (NIH) (see Nature 357, 103; 1992).

Although Congress left untouched many of the agricultural projects that President George Bush had initially marked for deletion, it - led by Senator Robert Byrd (Democrat, West Virginia) - gave no quarter to the NSF and NIH. All 31 of the NSF projects Byrd had targeted as "executive branch pork" (including "Holism in psychobiology in the twentieth century" and an NIH study on why patients are afraid to go to the dentist) are slated to go. The language, however, may offer NSF a slight loophole - it requires a $\$ 2$ million cut but only "strongly suggests" that the money come from the 31 offending projects. NSF officials, who know on which side their bread is buttered, are wary of going against Congress' wishes. But they are reviewing their options to see if there is some way in which they can cut an equivalent amount elsewhere in their budget and leave most of the scorned grants untouched.

Christopher Anderson

\section{India claims market drives US ban on space contracts}

New Delhi. The Indian government says that a US ban on space contracts with the US government and companies is really intended to cripple its commercial space programme rather than uphold the principles of an international agreement to prevent the spread of nuclear weapons.

The United States last week imposed a two-year ban on exports to and contracts with the Indian Space Research Organization (ISRO) in retaliation for India's decision to continue its $\$ 80$-million contract with the Russians for cryogenic rocket engines. US officials believe that the contract violates the guidelines of the missile technology control regime (MTCR), which Russia has promised to follow, while the Indian government insists that the engines do not fall under the terms of the agreement (see Nature 357, 99; 1992).

The head of the Indian space agency, U.R. Rao, says that the United States did not object when a US company, General Dynamics, offered to sell the engines to India two years ago. ISRO rejected the offer because the cost was three times more than the bid by Glavkosmos, the Russian space agency, and the company did not promise to share the technology with Indian scientists. His agency has already paid one-third of the overall cost, and he said that the US pressure was "unjustified". The ban seems unlikely to harm India's rocket programme, Rao said. Three projects that rely very little on imported technology - an intermediate range ballistic missile and two satellite launch vehicles - are moving forward, as is the project to provide engines for the second stage of a geostationary launch vehicle.

At the same time, the ban could severely damage the country's plans to enter the commercial space market. Two remote sensing satellites now in orbit and a communications satellite to be launched next month by Ariane contain a significant amount of foreign technology. There is no way that India can quickly develop the ability to make these parts.

"The US embargo will no doubt mean a delay and cost overruns", says Rao, "but we will survive". Alternate suppliers may be scarce, he added, if other countries need a US call to impose their own ban on sales to ISRO.

If the embargo spreads, India may have to abandon its plans to become a global player in space. The ban on US contracts has already removed US tracking stations from their expected role in tracking next month's launch of the communications satellite INSAT-2A, as well as existing agreements to receive images from Landsat and NOAA satellites.

K.S. Jayaraman 